Father Cortie states that the widening of some oxygen lines in sun-spot spectra, particularly in the $\alpha$ band, seems to be a real phenomenon.

Eclipse Observations.-Vol. iii. of the Annalen of the Royal University Observatory of Strassburg, edited by Dr. E. Becker, the director, contains the results of the heliometer observations of the total solar eclipse of May 28, 1900 , and of the lunar eclipses which took place on January 28, I888, May Ir, I902 (partial eclipse), and April IX, 1903, respectively.

In the first part Prof. Kobold gives the results of a number of observations made in order to determine the reduction elements of the heliometer, and then applies them to the observational results obtained during the solar eclipse of 1900. Finally, he gives the corrections to the apreviously determined positions. In part ii. the same observer discusses the observations of the 1888 and 1892 eclipses of the moon, and gives the values obtained for the radius of the earth's shadow, \&c., finally comparing them with the calculated values.

In the third part Herr C. W. Wirtz discusses the observations of the lunar eclipse of April II, 1903, including the corrections to the moon's place, the figure and size of the earth's shadow, and the variations of the diameter of the crater Linné during the eclipse. The curve on which are plotted the values of the last named quantity shows a considerable increase in the diameter during the approach of the earth's shadow to the crater, the maximum value evidently occurring during the actual eclipse of Linné.

The Appearance of Spark Lines in Arc Spectra.-An interesting discussion of the conditions which lead to the appearance of "spark" lines in arc spectra is published in No. 4, vol. xx., of the Astrophysical Journal by Dr. Henry Crew, of the North-western University, I11. Dr. Crew made a number of experiments in which the $\mathrm{Mg}$ line at $\lambda$ 448I appeared in the arc spectrum, and examined the arc, simultaneously, with a Rowland grating spectrograph and a Duddell high-frequency oscillograph.

The various conditions under which the arc was produced were as follow:- ( $\mathrm{I}$ and 2) current with negligible and with large amount of inductance respectively; (3) arc broken by air blast; (4) arc in atmosphere of coal gas.

The reproductions of the oscillograph curves show the current conditions during each experiment, and from a discussion of the results Dr. Crew arrives at the following conclusions:-(I) A rapidly changing, high E.M.F. is a probable conditio sine qua non for the appearance of spark lines in arc spectra. (2) The effect of hydrogen and other atmospheres in introducing spark lines is explained by the fact that these atmospheres produce a more rapid break, and this, in turn, introduces an extra E.M.F., which in some way, as yet unknown, is responsible for the radiation of the spark line. A possible explanation of the stellar conditions which produce spark lines in the spectra of stars is also discussed.

The Royal Astronomical Society of Canada.-Founded as the Astronomical and Physical Society of Toronto, the name of this society was changed in 1900 to that of the Toronto Astronomical Society. In 1903 it was decided to change its name to the Astronomical Society of Canada, and in response to a petition the privilege of prefixing the word "Royal" to its name was granted, so that the full title of the society is now the above heading. We hope that this now national society will be a stimulus to the promotion and diffusion of astronomical science, and that its influence will be greatly extended. We have before us the volume containing the selected papers and proceedings for the years 1902 and 1903 , edited by A. Harvey; the varied topics there dealt with bid fair for the future of the society. Among some of the papers may be mentioned the address of the president, R. F. Stupart, director of the Magnetic and Meteorological Observatory of Toronto, in which is an account of the history and work of the institution. W. H. S. Monck gives a catalogue of aërolites, arranged in order of the months in which they fell. There is a brief account of the present astronomical equipment of Canada as a whole, and a discussion on papers dealing with solar phenomena and terrestrial effects. The volume concludes with an account of women's work in astronomy, by Miss E. A. Dent.

$$
\text { No. } 1833, \text { VOL. } 71]
$$

\section{THE FIRST TRUE MAPS.}

$\mathrm{I}$ the history of cartography, in the development of maps and map-making, there is perhaps nothing quite comparable to the first appearance of the "portolani" or "handy charts" at the close of the thirteenth and the beginning of the fourteenth century. For the portolani, the first true sea-charts, are also the first true maps of any kind-the earliest designs in which any part of the earth-surface is laid down from actual observation of close and continuous character.

By the term "portolani" we intend, of course, to refer to that great series of coast-plans of which the earliest known examples belong to the first decade of the fourteenth century (A.D. I300-13IO); which are traceable to a very few, perhaps to two or three (now lost), originals; which may be extended to cover at least 500 designs (reaching down to the end of the sixteenth century); and were primarily intended to serve as practical guides to mariners and merchants in the seaports of the Mediterranean and Black Sea.

These plans of practical navigators - of men whose livelihood largely depended on their knowledge of nature and their close observation of natural features-are a remarkable contrast, in their almost modern accuracy, to the results of the older literary or theological geography as we have them in the Hereford or Ebstorf maps (both of the very same period as the oldest existing portolans, c. A.D. 1300). They have never yet received adequate attention from English geographers (as from Nordenskjöld the Swede, Fischer the German, or Uzielli the Italian), and the problem of their sudden appearance in such comparative perfection is surely deserving of more study, and capable of fuller explanation, than it has yet received. Certain assumptions may perhaps be made without danger. The portolano type was not the invention of one man, of one year, of one decade. It did not spring from any school or any example of mediæval student-map. It was the final result of centuries' experience-the outcome of the notes, plans, and oral tradition of generations of pilots and captains. Skipper-charts of certain important and muchfrequented sections of the coast trade-routes were probably combined, by slow degrees, into a coast-chart of the Mediterranean basin as a whole. It may be that the sketches of small portions of shore-line which we have in fifteenth century manuscripts of Leonardo Dati's poem "La Sfera" are really copies, but slightly modified, of such old skipper-charts-reaching back, perhaps, to the eleventh century, and forming the very earliest indications of that new scientific geography in which the compass played so great a part. If this surmise is correct, the opening of the mediæval Renaissance, in the generations immediately preceding the Crusades, was accompanied by the oldest embryonic forms of modern cartography.

Once more, it may be that the sea-chart which is mentioned in connection with the Seventh Crusade (of A.D. 1270), and which St. Louis apparently employed to aid his attack on Tunis, was a portolan, or a sectional chart of the North African coast of portolan type. It may be that the charta noticed in Raymond Lulli's "Arbor Scientiæ" (about A.D. I300) as necessary for sailors-along with the compass, needle, and "star of the sea"-was a work of the same kind. 'It may be that Andrea Bianco's planisphere of 1436 is a re-edition of a "handy-map" of the thirteenth century. But the oldest certain examples of the type we are concerned with, which have been discovered up to the present, are the Carte pisane and the first design of Giovanni de Carignano, both belonging to the opening years of the fourteenth century, while the oldest dated portolan is the first of Pietro Vesconte (or Visconti), executed in $\mathrm{r} 3 \mathrm{r}$.

And when, with these and the next few examples, we get at last our full coast-chart of the Mediterranean basin, what is its character?

It is a map without graduation, embracing only the coast lines and the towns and natural features in the immediate neighbourhood of the coast. But though it is restricted, it has extraordinary merits in its own field. Its delineation of the shores of the Mare Internum, from the Straits of Gibraltar to the extreme east of the Black Sea, is markedly superior to anything of earlier date-even to the Madaba 
mosaic of the sixth century or to Matthew Paris's thirteenth century " England." The chief errors which Ptolemy had imparted to the shape of the Mediterranean are corrected. The main features of the great inland sea are presented with a correctness and a minute detail which, at the most casual glance, immediately distinguish portolan work from any preceding variety of cartography. No attempt is made to fill up the interior of the lands-continental or insular-of which the coasts are portrayed; such attempts are made later, it is true, but they are obvious and confessed additions to the primitive, normal, or typical portolan. But, along the shores in question, all points important for navigation are drawn with great care; small islands, bays, cliffs, and headlands - of no great general importance, but vital to the coaster-are often depicted in disproportionate size; all the ports especially suitable for calling, watering, and revictualling are indicated with the especial honour of red colouring; even shallows are frequently marked, denoted by a sign still used at the present day; the very large number of shore-names testifies to the minute knowledge underlying the work. Thus along the north coast of the Mediterranean we have (by A.D. I320) about 620 names; on the coasts of the Black Sea and Sea of Marmora about 260 ; on the coasts of Asia Minor and Syria about 160 ; on the north coast of Africa about 240; in all some 1280 , without counting island names-which are very numerousor the names which fringe the western coast of Europe to the mouth of the Elbe, and the western coast of Africa to Cape Nun, or Non, at the extreme south-west of Morocco. In respect to these shores-let us say from Hamburg almost to the Wady Draa, and from Gibraltar to Azov, Poti, Batum, Alexandretta, Jaffa, and the Nile--the portolani soon become fixed in the pattern they permanently retained, a pattern which gradually triumphs over every other-even the revived Ptolemaic, to which scholars clung so desperately and so unhappily. We may therefore regard the great mass of these works as mere copies of a few normal or typical designs which were completed (at least in all their essential parts) before the outbreak of the Hundred Years' War, and a good twenty years before the battle of Crecy. How closely the original type was followed may be guessed from the fact that the portolan colours-used according to certain definite rules-are unaltered for long periods of years, and through scores of examples. Thus red or reddish-brown is always kept for the Red Sea, and long after the Turkish conquest of Rhodes that island regularly appears in white with a black cross.

Instead of lines of latitude and longitude (or substitutes for such lines, as we find in the "Palestine" of Marino Sanuto, c. A.D. 1310), a net of loxodromes is employed on (or has, at any rate, been added to) the portolani even of the earliest time. These loxodromes are straight lines in the direction of the various winds, proceeding from a number of crossing-points regularly distributed over the map. But in this loxodrome net-work, in sharp contrast to all other features of the portolan map-type, there is almost infinite variation; one seldom comes across two designs of exactly similar character in this respect.

A distance-scale, with the same unit of length, occurs on all the portolani; this unit (which has been called the portolan mile) is estimated with much care by Nordenskjöld at 5830 metres; while of all known mediæval measures, that which corresponded most nearly with the "portolan mile" seems to have been the Catalan legua. A Catalan league therefore, it is suggested, may have furnished the basis of the portolan measure, and the portolan type of map may have originated (in part at least) among Catalan mariners.

Baron Nordenskjöld, indeed, does not hesitate to ascribe to the portolani an entirely Catalan parentage. But, admitting that one germ of the first true maps may have existed at Barcelona or some other centre of Catalonian trade and seamanship, I cannot but think that another germ still more active and important was to be found in Italy, and above all in the north-west-in Genoa and Pisa. For, remembering the indications in Dati's "Sfera," we may agree with Theobald Fischer that map sketches of portolan type, and with the practical object of helping navigation, were almost certainly drawn in Italy, and by Italians, before 1300 . Remembering, also, that of the No. I 833 , VOL. 7 I] existing portolani all the earliest examples are unquestionably Italian-and that, of some 500 known, 4I3 were executed by the countrymen of Carignano and Vescontewe shall not be ready to deprive Italy of the first place in the creation of the oldest scientific maps. Even if that creation was, as seems probable, an "Homeric" feat-the piecing together (with additions and improvements) of a great number of small sectional coast-surveys-yet this earlier stage, only recorded in Italian manuscripts, seems no less due to the seamen of the peninsula.

Can we throw any other light upon the origin of the portolani?

In 188 I Fiorini suggested that West-European mariners, such as those of Italy, learnt from the Byzantines the art of making and using maps founded on careful draughtsmanship and close study of distance (i.e. portolani of a kind) as early as the eleventh century. This idea has been accepted by Theobald Fischer, and has been treated with great respect by other scholars. Yet it is surrounded by difficulties. For no Greek portolan has yet been found, nor is Greek influence anywhere to be detected in the language, legend-allusions, contours, or other details of the early portolani. Fragments of Latin, fragments of Italian and Catalan dialects, fragments of a lingua franca composed of various Romance tongues-these are the media through which the early portolan draughtsmen convey information. But of Greek they make no use, and of Byzantine geography, history, harbours, or coast routes they show no special knowledge. We may give weight to the fact that the Byzantine navy was one of the chief Christian weapons in the ninth, tenth, and early eleventh centuries; that Constantinople was then the greatest trade centre in Christendom; and that the seamen of the Greek islands were very prominent in Mediterranean navigation in the age of the Byzantine revival (c. 860-ro6o A.D.). But all this is far from proving a Byzantine right to the "invention " of the portolan coast-chart, ${ }^{1}$ even in the primitive form of sectional pilot-maps of limited areas.

It only remains to say that all genuine progress in geographical delineation followed the lines of the portolani; that the accurate methods employed by them for coast-work were gradually applied to the interior of countries; that in spite of the contempt shown for them by most of the learned in the so-called Renaissance period, they were at last known by their fruits and vindicated by the success of their type.

Ancient classical or pre-Christian maps were not without certain merits, though we can only judge of them by the two remaining examples, the Peutinger table, originally a road-map of Augustus's Empire, and the designs illustrating the "Geography" of Claudius Ptolemy of Alexandria-both surviving only in manuscripts of the central mediæval period. After the modern age of oceanic discovery had passed through its earliest and most difficult stages, the Renaissance editions of Ptolemy (from 1474) played a very important part in delaying geographical progress and retarding the history of civilisation. But in the time of the early portolani (say from 1300 to 1400 ) neither the work of the Alexandrian astronomer nor the road-maps of the Roman Empire were adequately known in western Europe. The sixteenth and seventeenth centuries were not so innocent.

Designs of the portolan type do not seem to have existed even in the best ages of classical geography and exploring activity; the old peripli were sailing directions, not drawn, but written; and the only Arabic scheme of the sort which has yet been found is certainly copied from a Christian -and Italian-original.

It is in the portolani, and especially in such a work as the Laurentian design of 1351 , with its revelations of the Azores and the Madeira group, and its still more startling suggestion of the true shape of Africa, that we may find, perhaps, the chief geographical teachers of Henry the Navigator and his Portuguese. Never better than in these long-neglected charts does the history of civilisation illustrate man's change from empirical to scientific, from traditional booklearning to the investigation of nature. The portolani long

1 To Nordenskjold's wild theory, "Facsimile Atlas," p. 48, that Marinus of Tyre is the real original portolan draughtsman, and that the Marinus maps which Masudi saw before A.D. 956 were really portolani, we need not pay attention. 
suffered, in general appreciation, from the fact that-in their essential features-they never attempted to gratify popular taste; that they did not, with rare exceptions, illustrate $^{1}$ the works of fashionable writers, whether classical philosophers or mediæval prelates; that they had no connection with the legends and dreams of chivalry and romance; that they were not the work of schools or courts; and that they owed nothing to Ptolemy or Strabo. But we know their worth better now.

They first record for us the new discoveries among the Atlantic islands and along the African mainland; they guide and accompany the faltering steps of our race in the outward, oceanic, movement of European life; in them true cartography, the map-making of the civilised world, begins.

\section{Raymond Beazley.}

\section{GEOLOGICAL NOTES.}

$S$ TATISTICS of mineral production in India in the ten years 1894 to 1903 have been issued by the Government of India (Department of Revenue and Agriculture, 1904). In the report for 1903 satisfactory progress in the mining industry is recorded. There has been a remarkable development in the production of petroleum and manganese ore, and a continuation of the progress previously recorded for coal and gold.

From the Geological Survey of India we have received part ii. of the newly re-issued Records. Mr. T. H. Holland, director, contributes a short appreciative memoir of the late General C. A. McMahon, and among other articles there is a well illustrated report by $\mathrm{Mr}$. J. Malcolm Maclaren on the auriferous occurrences of Chota Nagpur, in Bengal. The conclusion is that there is little scope for the legitimate investment of capital in the recovery of gold, whether from the quartz veins or from the superficial deposits, but that the greater portion of the gold must be left to the native washer, "forming for him a reserve that, though it will never raise him to affluence, will always lift him beyond the grasp of famine." Two minerals, thenardite and cancrinite, are recorded for the first time from India. We have also received a report on the geology of Spiti, by $\mathrm{Mr}$. H. H. Hayden (Mem. Geol. Surv. India, vol. xxxvi., part i.). Hitherto no systematic survey had been made of the region, and the results of this work, which was carried out by Mr. Hayden with the assistance of the late Dr. von Krafft, are depicted on a map to the scale of one inch to four miles, and further illustrated by some striking pictorial views and sections. The formations represented are Cambrian, Silurian, Carboniferous and Permian, Trias, Jurassic, and Cretaceous, with also intrusive rocks. The oldest sedimentary rocks belong to the Middle Haimanta division of Mr. Griesbach; they are unfossiliferous, and are overlain presumably by the Upper Haimantas, in which Lingulella and Olenus have been found. Lower and Upper Silurian rocks are recognised, and from these and the later formations many fossils are recorded.

The ammonite fauna of the Spiti shales forms the subject of a monograph by Dr. Victor Uhlig ( $\mathrm{Mem}$. Geol. Survey, India, ser. xv., vol. iv.). Only the first portion of this work has at present been issued, and in it the author deals with the genera and species of Ammonoidea. With regard to the classification, the author remarks that as no universally satisfactory agreement has yet been reached, he gives the descriptions of the various forms in unclassified sequence, while indicating their approximate position. In the course of his work he has studied as far as possible all the old as well as new material, and he has found it necessary to re-figure and describe many of the species previously published.

In mineralogical notes contributed by $\mathrm{Mr}$. A. K. Coomaraswamy (Spolia Zeylanica, August), reference is made to the occurrence in Ceylon of thorium-bearing minerals, of corundum-sillimanite rocks, kyanite, serendibite, \&c. The same author, in dealing with the geology

1 Some of the atlases founded on portolani, such as the Carte Catalane of 1375. really illustrate the travels of the thirteenth and fourteenth centuries, e.g. Marco Polo's. But this is strictly in the way of explanation of a great eographic text.

NO. I833. VOL. 7 I] of Ceylon (Geol. Mag., August), proposes the name Balangoda group for a series of granitic and pegmatitic rocks intrusive in the Charnockite series. The group includes granites with zircon, allanite, magnetite, \&c.

The summary of progress of the Geological Survey for the year 1903 contains the usual particulars of the field work which has been carried on in Cornwall, Derbyshire and Nottinghamshire, Carmarthenshire and Pembrokeshire, in various parts of Ross-shire and the western highlands, in the Edinburgh coal-field, and in the neighbourhood of Cork in Ireland. Special attention is directed to the discovery in Ross-shire of a rock essentially composed of magnetite and cassiterite-the occurrence of tin-ore being new; but it is stated that at present there is no reason to believe that the tin-bearing rock occurs in any large masses. In an appendix Dr. J. S. Flett contributes first notes on the petrography of western Cornwall, dealing with some of the garnetiferous greenstones, the granites and greisen veins, and the phenomena of contact alteration; Mr. H. B. Woodward writes on the Geological Survey in reference to Agriculture, with report on the soils and subsoils of the Rothamsted estate; and $\mathrm{Mr}$. H. A. Allen continues the important catalogue of types and figured specimens of fossils in the Museum of Practical Geology, with a record of Oolitic Gasteropoda and Scaphopoda.

The general report and statistics on mines and quarries for I903, part iii. (output), has been issued by the Home Office. The total value of the minerals raised during the year showed a decrease of $5^{\frac{1}{4}}$ million pounds as compared with 1902-a decrease arising from the fall in price of coal. The total output of coal was the highest hitherto recorded. The outputs of ores of iron, copper, and lead show increase, while those of manganese, tin, and uranium ores show decrease.

In the Proceedings of the Bristol Naturalists' Society (n.s., vol. x., part iii.) Prof. Lloyd Morgan and Prof. S. H. Reynolds give particulars of the field relations of the Carboniferous volcanic rocks of Somerset. There is also an interesting article by $\mathrm{Mr}$. W. H. Wickes on the Rhætic bone-beds, the author pointing out that there is no regular and persistent bed, but thin layers of varying extent occur on different horizons, due to the former presence and destruction of shoals of carnivorous fishes and saurians, while the occurrence of small pebbles in the bone-beds is attributed to the fact that large sea fish often have stones in their stomachs. Mr. H. B. Woodward contributes a memoir on the late Robert Etheridge, dealing more especially with his work in the Bristol area.

In the Proceedings of the Cotteswold Naturalists' Field Club (vol. xv., part i.) Messrs. J. W. Gray and G. W. S. Brewer direct attention to the evidence of a Celtic settlement on Cleeve Hill, prior to the Roman occupation of that part of the country; among the domestic animals were the horse, ox, sheep, pig, dog, and fowl. Mr. L. Richardson contributes an article on the Rhætic beds of Worcestershire.

A study of sands and sediments has been commenced by Mr. T. Mellard Reade and Mr. Philip Holland (Proc. Liverpool Geol. Soc., I904). So far as their investigations have proceeded, they are led to believe that purely mechanical micro-sediments may constitute a much larger proportion of the rocks than has been hitherto suspected. Moreover, their experiments show the persistent retention of detrital carbonate of lime in extremely fine subsidence-matter, and suggest that deep-sea limestones may sometimes be formed as detrital accumulations.

The twenty-eighth annual report of the Department of Geology and Natural Resources, Indiana, under the direction of Mr. W. S. Blatchley, State geologist, is accompanied by an excellent geological map of the State on the scale of an inch to four miles, with explanatory descriptions by $\mathrm{Dr}$ T. C. Hopkins and Dr. A. F. Foerste. The formations represented are Ordovician, Silurian, Devonian, Lower Carboniferous, and Coal-measures. The petroleum producing areas are specially marked, that industry having become one of the greatest in the State. Special reports are contributed on this and on the lime industry, and there is also an article on the stratigraphy and palæontology of the Niagara formation by Mr. E. M. Kindle, with twenty-five plates of fossils. 